\title{
Badanie technologii spawania wiązką elektronów stali do ulepszania cieplnego w gatunku 42CrMo4
}

\author{
Examination of electron beam welding procedures \\ for quenching and tempering 42CrMo4 steel grade
}

\section{Streszczenie}

W referacie przedstawiono wyniki badań metalograficznych oraz pomiarów twardości złączy spawanych wiązką elektronów wykonanych ze stali do ulepszania cieplnego w gatunku 42CrMo4. Celem badań było sprawdzenie możliwości wykonania złączy spawanych przy wykorzystaniu specjalnych technik spawania wiązką elektronów, tj. spawania z podgrzewaniem wstępnym, spawania wiązką oscylującą oraz spawania za pomocą techniki wieloprocesowej. Przeprowadzone badania wykazały, że zastosowanie specjalnych technik spawania wiązką elektronów umożliwia obniżenie twardości w obszarze SWC oraz w spoinie. Ponadto możliwe jest wyeliminowanie pęknięć w obszarze spoiny.

Słowa kluczowe: spawanie wiązką elektronów; stal do ulepszania cieplnego; specjalne techniki spawania

\begin{abstract}
In the paper the results of metallographic examination and hardness testing of electron beam welded joint for quenching and tempering $42 \mathrm{CrMo} 4$ steel grade are presented. The aim of the study was to examine the feasibility of correct welded joints using special electron beam welding techniques based on dynamic deflection of the electron beam, ie., welding with preheating, welding with beam oscillation and using the multiprocessing technique. The research showed that using special techniques of electron beam welding can reduce hardness in the area HAZ and in the weld. It is also possible to eliminate cracks in the weld area.
\end{abstract}

Keywords: electron beam welding; steel for quenching and tempering; special electron beam welding techniques

\section{Wstęp}

Wiele elementów maszyn i urządzeń jest wytwarzanych ze stali stopowych do ulepszania cieplnego. Stale te uważane są za materiały o ograniczonej spawalności, a uzyskanie poprawnych złączy wiąże się z szeregiem trudności technologicznych. Równocześnie można zauważyć, iż charakterystycznymi cechami procesu spawania wiązką elektronów jest duża gęstość mocy co umożliwia osiąganie dużych prędkości nagrzewania i stygnięcia spawanego materiału w obszarze spoiny. W konsekwencji może to powodować wzrostu twardości i powstawania pęknięć w obszarach spoiny oraz SWC, nawet w przypadku dobrze spawalnych materiałów $[1,2]$.

Niekorzystne zjawiska mogą być jednak ograniczone lub wyeliminowane, poprzez zastosowanie specjalnych technik spawania, których rozwój jest możliwy dzięki wyposażaniu urządzeń do spawania wiązką elektronów w zaawansowane technologicznie, sterowane numerycznie generatory funkcji odchylania wiązki elektronów [3].

W trakcie spawania wiązką elektronów stali o podwyższonej hartowności szczególną uwagę należy zwrócić na występowanie pęknięć zimnych. Pęknięcia tego rodzaju występują w spoinie, przede wszystkim pod postacią pęknięć wzdłużnych, a także pęknięć poprzecznych. Nie występują natomiast w SWC, najprawdopodobniej ze względu na niewielką ilość wodoru dyfundującego oraz niewielkie naprężenia wynikające z niewielkiej objętości i charaktery-

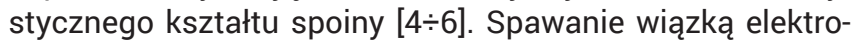
nów w próżni sprzyja przeciwdziałaniu kruchości wodorowej pod warunkiem, że z powierzchni elementów spawanych zostaną dokładnie usunięte zanieczyszczenia stanowiące źródło wodoru [7].

Biorąc pod uwagę powyższe można założyć, że głównymi czynnikami wpływającymi na skłonność do pęknięć zimnych w przypadku spawania wiązką elektronów jest skład chemiczny materiału spawanego oraz szybkość stygnięcia spoiny i SWC.

Równoważnik węgla wyliczony na podstawie ilości określonych składników stopowych odzwierciedla prawdopodobieństwo wytworzenia struktur hartowniczych ze względu na skład chemiczny. Prędkość stygnięcia jest funkcją energii liniowej spawania, kształtu złącza oraz temperatury podgrzewania wstępnego [8]. W przypadku spawania metodami łukowymi praktycznie ustalono, że jeśli wartość równoważnika węgla $\mathrm{Ce}<0,45 \%$ to materiał można uznać za dobrze spawalny, a twardość w SWC zazwyczaj nie przekracza 380 HV. Zjawiskiem charakterystycznym dla procesu spawania wiązką elektronów jest brak pęknięć w spoinie przy twardości znacznie wyższej - około 600 HV [4,5]. Przeciwdziałanie pojawianiu się struktur hartowniczych w spoinie może

Mgr inż. Sylwester Błacha; mgr inż. Jerzy Dworak - Instytut Spawalnictwa.

Autor korespondencyjny/Corresponding author. sylwester.blacha@is.gliwice.pl 
zatem polegać na celowym wydłużeniu czasu stygnięcia t8/5. Uzyskaniu tego rodzaju efektu może sprzyjać:

- zwiększenie energii liniowej procesu i precyzyjny doboru parametrów spawania, odpowiednio do materiałów łączonych, i (lub) stosowanie wstępnego podgrzewania strefy złącza przed spawaniem, a także wygrzewanie po spawaniu,

- zastosowanie oscylacji wiązki elektronów ogniskowanej w jednym obszarze,

- zastosowanie tzw. techniki wieloprocesowej, czyli procesu, w którym wszystkie zabiegi (np.: podgrzewanie, spawanie, wygrzewanie) prowadzone są w tym samym czasie.

W pracy przedstawiono wyniki badań metalograficznych oraz pomiarów twardości złączy wykonanych ze stali do ulepszania cieplnego w gatunku 42CrMo4, spawanych wiązką elektronów. Celem badań było zbadanie wpływu podstawowych parametrów procesu spawania stali przy wykorzystaniu specjalnych technik na budowę strukturalną i twardość w obszarze spoiny oraz SWC.

\section{Metodyka badań, materiał do badań}

Badania polegały na opracowaniu i zbadaniu działania funkcji dynamicznego odchylania wiązki elektronów w od- niesieniu do wieloprocesowej techniki spawania. W ramach pracy wykonywano doczołowe złącza jednoimienne z obwodową spoiną czołową. Elementy próbne stanowiły wałki o średnicy $48 \mathrm{~mm}$ ze stali w gatunku 42CrMo4. Wałki były spawane z niepełnym przetopem.

Skład chemiczny stali 42CrMo4 wg PN-EN 10083-3 [9] przedstawiono $\mathrm{w}$ tablicy I.

W ramach pracy zastosowano następujące technik spawania:

- z podgrzewaniem wstępnym za pomocą rozogniskowanej lub oscylującej wiązki elektronów,

- za pomocą wiązki oscylującej, bez podgrzewania wstępnego,

- z techniką wieloprocesową (podgrzewanie wstępne, spawanie i wygrzewanie prowadzone w jednym cyklu spawania).

Złącza zostały wykonane przy użyciu urządzenia do spawania wiązką elektronów model XW150:30/756 zainstalowanego w Instytucie Spawalnictwa w Gliwicach. Zastosowane parametry technologiczne spawania zostały przedstawione w tablicy II.

\section{Określenie temperatury wstępnego podgrzewania}

Według wytycznych technologicznych dotyczących spawania elementy o grubości do $25 \mathrm{~mm}$ ze stali w gatunku 42CrMo4 powinny być wstępnie podgrzane przed spawaniem

Tablica I. Skład chemiczny stali 42CrMo4 [9]

Table I. Chemical composition of the $42 \mathrm{CrMo} 4$ steel

\begin{tabular}{|c|c|c|c|c|c|c|c|c|}
\hline \multicolumn{10}{|c|}{ Skład chemiczny stali [\%] max } \\
\hline C & Si & Mn & Cr & Mo & Cr & P & S & $C_{e}$ \\
\hline 0,45 & 0,40 & 0,90 & 1,20 & 0,07 & 0,30 & 0,025 & 0,035 & 0,71 \\
\hline
\end{tabular}

Tablica II. Parametry technologiczne stosowanych technik spawania wiązką elektronów Table II. The technological parameters of applied electron beam welding techniques

\begin{tabular}{|c|c|c|c|c|c|c|}
\hline $\begin{array}{c}\text { Oznaczenie } \\
\text { techniki } \\
\text { spawania }\end{array}$ & $\underset{[k V]}{U}$ & $\begin{array}{c}\mathrm{I} \\
{[\mathrm{mA}]}\end{array}$ & $\begin{array}{c}\mathrm{v}, \mathrm{F} \\
{[\mathrm{mm} / \mathrm{min}]}\end{array}$ & $\begin{array}{c}\mathrm{h} \\
{[\mathrm{mm}]}\end{array}$ & $\begin{array}{c}\mathrm{A} \\
{[\mathrm{mm}]}\end{array}$ & $\begin{array}{c}\mathbf{f} \\
{[\mathrm{Hz}]}\end{array}$ \\
\hline $\begin{array}{c}\text { Bez } \\
\text { podgrzewania } \\
\text { wstępnego }\end{array}$ & 150 & 32 & 3950 & 385 & - & - \\
\hline \multirow{2}{*}{$\begin{array}{c}\text { Z podgrzewaniem } \\
\text { wstępnym }\end{array}$} & 150 & $8 *$ & $800 *$ & 385 & - & 10 \\
\hline & 150 & $32 * *$ & $3950 * *$ & 385 & - & - \\
\hline $\begin{array}{c}\text { Spawanie } \\
\text { z jednoczesnym } \\
\text { podgrzewaniem }\end{array}$ & 150 & 42 & 3950 & 385 & - & 600 \\
\hline $\begin{array}{c}\text { Spawanie } \\
\text { jednoczesnym } \\
\text { podgrzewaniem } \\
\text { i wygrzewaniem }\end{array}$ & 150 & 52 & 3950 & 385 & - & 600 \\
\hline $\begin{array}{l}\text { Oscylacjami } \\
\text { eliptycznymi }\end{array}$ & 150 & 32 & 3950 & 385 & 0,55 & 868,2 \\
\hline $\begin{array}{l}\text { Oscylacjami } \\
\text { ósemkowymi }\end{array}$ & 150 & 32 & 3950 & 385 & 0,55 & 868,2 \\
\hline \multicolumn{7}{|c|}{$\begin{array}{l}\text { U-napięcie przyspieszające, } \\
\text { I-natężenie prądu wiązki elektronów, } \\
\text { v-prędkość spawania [mm/min], } \\
\text { h- odległość elementu od górnej powierzchni ściany komory roboczej, } \\
\text { A- amplituda oscylacji wiązki elektronów, } \\
\text { f - częstotliwość oscylacji wiązki elektronów, } \\
\text { *-parametry technologiczne dla podgrzewania wstępnego, } \\
\text { «*-parametry technologiczne spawania }\end{array}$} \\
\hline
\end{tabular}


do temp. w zakresie $300 \div 450{ }^{\circ} \mathrm{C}$ [10]. Temperaturę podgrzewania wstępnego można również wyznaczyć z zależności opracowanych przez Seferiana [11,12] oraz Ito i Bessyo [13].

Wyznaczona temperatura podgrzewania wstępnego elementów próbnych mieści się w przedziale wartości od $212^{\circ} \mathrm{C}$ (wg Seferiana) do $418{ }^{\circ} \mathrm{C}$ (wg Ito i Besyo). Do prób technologicznych spawania elementów próbnych w postaci wałków przyjęto zatem trzy wartości temperatury podgrzewania wstępnego: $200^{\circ} \mathrm{C}, 300^{\circ} \mathrm{C}$ i $400^{\circ} \mathrm{C}$.

Podgrzewanie prowadzono stosując taką ilość cykli ruchu obrotowego, aby osiągnąć założoną temperaturę elementu. Wiązka oscylująca oddziaływała w dwóch obszarach w kształcie prostokąta o wymiarach $13,0 \times 6,5 \mathrm{~mm}$, rozłożonych symetrycznie wzdłuż styku łączonych elementów w odległości $2 \mathrm{~mm}$ od styku w każdą stronę. Schemat podgrzewania wstępnego wałków za pomocą wiązki elektronów przedstawiono na rysunku 1.
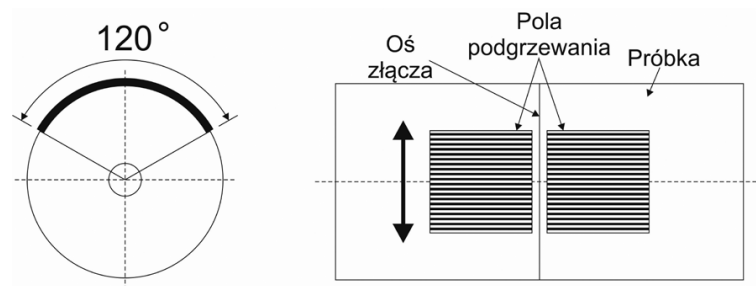

Rys. 1. Schemat podgrzewania wstępnego wałków za pomocą wiązki elektronów

Fig. 1. Schematic diagram of electron beam preheating

\section{Zastosowanie do podgrzewania}

\section{wstępnego techniki wieloprocesowej}

W procesie spawania za pomocą techniki wieloprocesowej w jednym procesie obróbki realizowano jednocześnie poszczególne procesy składowe, np. podgrzewanie i spawanie lub podgrzewanie, spawanie i wygrzewanie po spawaniu (rys. 2).

Wiązka elektronów „rozszczepiana" została na trzy wiązki składowe, przemieszane z określoną częstotliwością do poszczególnych obszarów obrabianych. W obszarze podgrzewania i wygrzewania wprowadzona została dodatkowo w oscylacje. W obszarze spawania oscylacja wiązki nie była stosowana. Każdemu z obrabianych obszarów przyporządkowana została określona moc wiązki składowej.

\section{Spawanie za pomocą wiązki oscylującej, bez podgrzewania wstępnego}

Kształtowanie geometrii spoiny oraz warunków krystalizacji spoiny umożliwiają również oscylacje wiązki elektronów.

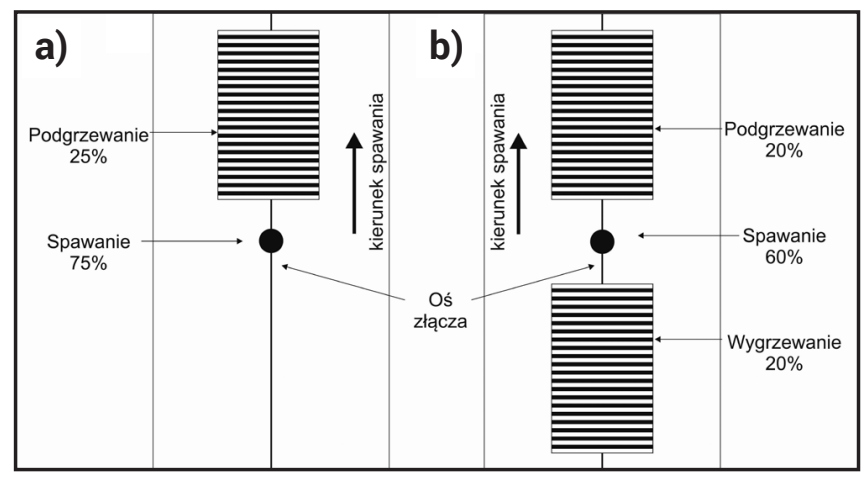

Rys. 2. Schemat spawania wiązką elektronów techniką wieloprocesową: a) z jednoczesnym podgrzewaniem, b) z jednoczesnym podgrzewaniem i wygrzewaniem po spawaniu

Fig. 2. Schematic diagram of multiprocessing technique of electron beam welding : a) with same time preheating, b) with same time preheating and heat treat after welding
W ramach pracy wykonano złącza próbne stosując oscylacje eliptyczne oraz ósemkowe (rys. 3).

Złącza spawane przy użyciu wiązki elektronów zostały poddane badaniom metalograficznym makro- i mikroskopowym zgodnie z PN-EN ISO 17639:2013-12 [14]. Próbki trawiono $2 \%$ nitalem. Obserwacje mikrostrukturalne prowadzono na mikroskopie świetlnym Eclipse MA200 firmy Nikon. Pomiary twardości przeprowadzono zgodnie z PN-EN ISO 9015-2:2011 [15] z uwzględnieniem PN-EN 15614-11 [16]. Twardość mierzono metodą Vickersa przy obciążeniu 9,81 N (HV1) przy użyciu twardościomierza automatycznego KB 50 Prüftechnik.

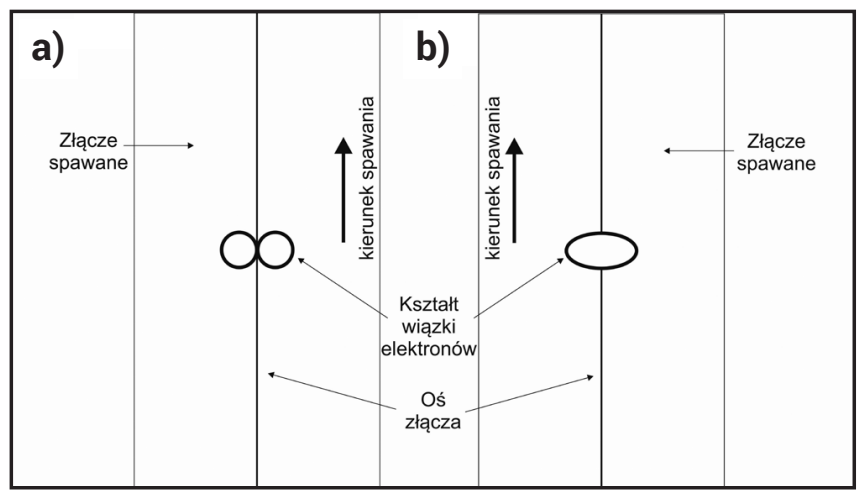

Rys. 3. Schemat oscylacji wiązki elektronów a) ósemkowa, b) eliptyczna

Fig. 3. Schematic diagram of the electron beam oscillation a) octal, b) elliptical

\section{Wyniki badań i ich dyskusja}

Próby technologiczne spawania przeprowadzono na elementach próbnych w postaci wałków ze stali w gatunku 42CrMo4. Stal w stanie dostawy charakteryzowała się mikrostrukturą martenzytu odpuszczonego o twardości 305 HV1.

Na rysunku 4 przedstawiono wyniki badań metalograficznych złącza spawanego konwencjonalnie natomiast na rys 5 przedstawiono wyniki badań złącza spawanego z podgrzewaniem wstępnym do temperatury $400^{\circ} \mathrm{C}$.
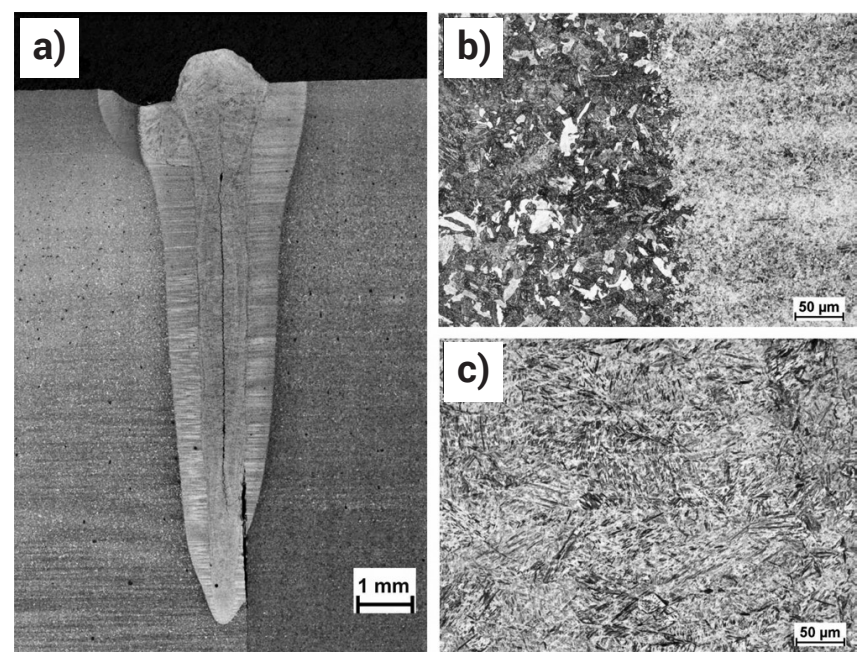

Rys. 4. Wyniki badań metalograficznych złącza doczołowego ze spoiną obwodową ze stali w gatunku 42CrMo4 spawanego wiązką elektronów bez podgrzewania wstępnego: a) widok złącza, b) obszar SWC, struktura: martenzyt, 254 HV, c) obszar spoiny, struktura: martenzyt, $710 \mathrm{HV}$

Fig. 4. The results metallographic examinations of electron beam welded butt joint of steel $42 \mathrm{CrMo} 4$ without the heat treat before welding: a) joint view, b) the area HAZ, structure: martensite, $254 \mathrm{HV}$, c) the area of weld, structure: martensite, $710 \mathrm{HV}$ 
Na podstawie przeprowadzonych badań (rys. 4) wykazano, iż w złączu spawanym wiązką elektronów stali w gatunku 42CrMo4 bez podgrzewania wstępnego występują charakterystyczne pęknięcia wzdłużne, typowe dla niewielkich energii liniowych spawania. Badania metalograficzne makroskopowe wykazały, że tego rodzaju pęknięcia mogą zostać w znacznym stopniu wyeliminowanie w wyniku zastosowania podgrzewania wstępnego do określonej temperatury (w przypadku stali $42 \mathrm{CrMo} 4$ do około $400{ }^{\circ} \mathrm{C}$ ). Wyeliminowanie pęknięć było związane z wydłużeniem czasu stygnięcia t8/5 [17]. Zastosowanie podgrzewania wstępnego umożliwiło również zmianę geometrii samej spoiny. Pomiary twardości w obszarze złączy spawanych z podgrzewaniem wstępnym elementów do temperatury $200{ }^{\circ} \mathrm{C}, 300{ }^{\circ} \mathrm{C}$ i $400{ }^{\circ} \mathrm{C}$ wykazały znaczące obniżenie twardości w obszarze spoiny i SWC w porównaniu do złączy wykonanych bez podgrzewania wstępnego. Twardość spoiny o wartości średniej 710 HV1 dla złącza spawanego wiązką elektronów bez podgrzewania wstępnego została obniżona do wartości średniej $586 \mathrm{HV} 1\left(200^{\circ} \mathrm{C}\right), 475 \mathrm{HV} 1\left(300^{\circ} \mathrm{C}\right)$, i $330 \mathrm{HV} 1\left(400^{\circ} \mathrm{C}\right)$.

W drugim etapie prowadzonych badań przeanalizowano wpływ wieloprocesowego spawania wiązką elektronów na budowę makro i mikrostrukturalną oraz twardość w obszarze spoiny oraz SWC. Wyniki badań metalograficznych przedstawiono na rysunkach 6 i 7.

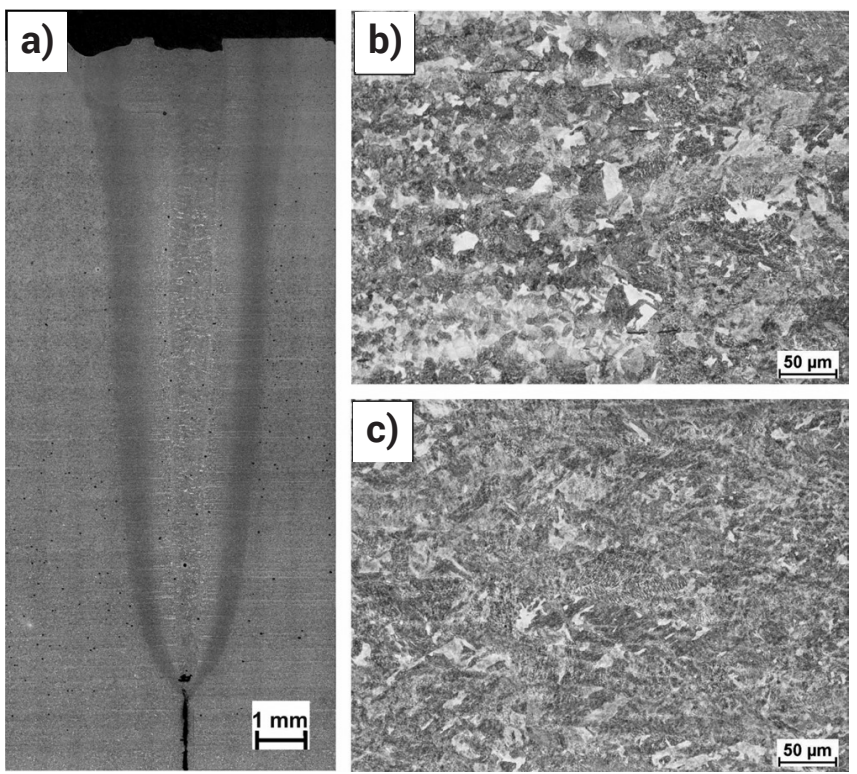

Rys. 5. Wyniki badań metalograficznych złącza doczołowego ze spoiną obwodową ze stali w gatunku 42CrMo4 spawanego wiązką elektronów z podgrzewaniem wstępnym do $400^{\circ} \mathrm{C}$ : a) widok złącza, b) obszar SWC, struktura: martenzyt, 320 HV, c) obszar spoiny, struktura: martenzyt, $330 \mathrm{HV}$

Fig. 5. The results metallographic examinations of electron beam welded butt joint of steel $42 \mathrm{CrMo} 4$ with the preheating to $400{ }^{\circ} \mathrm{C}$ : a) joint view, b) the area $\mathrm{HAZ}$, structure: martensite, $320 \mathrm{HV}, \mathrm{c}$ ) the area of weld, structure: martensite, $330 \mathrm{HV}$

Badania metalograficzne wykazały, że zastosowanie spawania z techniką wieloprocesorową umożliwia wyeliminowanie pęknięć wzdłużnych w spoinie co jest najprawdopodobniej związane ze zmianą w krystalizacji samej spoiny. Ponadto istnieje możliwość kształtowania geometrii spoiny. Równocześnie zaobserwowano jednak w obszarze spoiny pęknięcia poprzeczne.

W ostatnim etapie badań do wykonania złączy próbnych zastosowano oscylacje wiązki elektronów. Wyniki badań metalograficznych przedstawiono na rysunkach 8 i 9.

Analizując wyniki badań metalograficznych złączy spawanych wiązką oscylującą (rys. 8 i 9) można zauważyć,
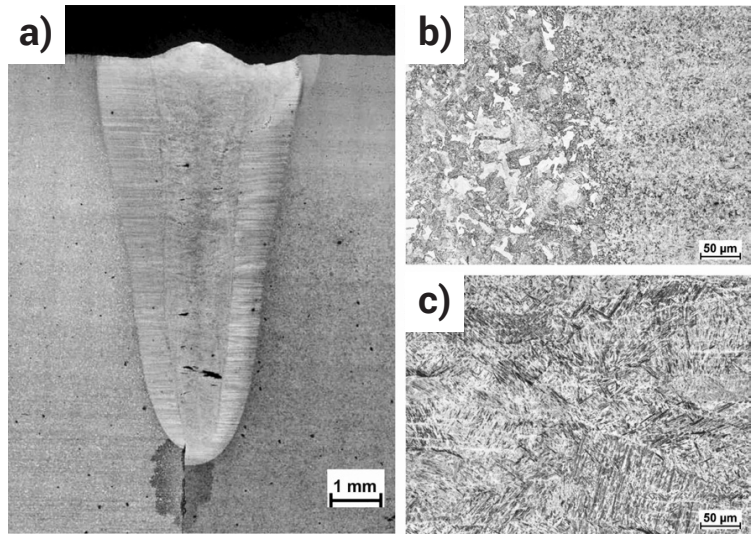

Rys. 6. Wyniki badań metalograficznych złącza doczołowego ze spoiną obwodową ze stali w gatunku 42CrMo4 spawanego wiązką elektronów z jednoczesnym podgrzewaniem: a) widok złącza, b) obszar SWC, struktura: martenzyt, 619 HV, c) obszar spoiny, struktura: martenzyt, $656 \mathrm{HV}$

Fig. 6. The results metallographic examinations of electron beam welded butt joint of steel $42 \mathrm{CrMo} 4$ welded with same time preheating: a) joint view, b) the area HAZ, structure: martensite, $619 \mathrm{HV}$, c) the area of weld, structure: martensite, $656 \mathrm{HV}$
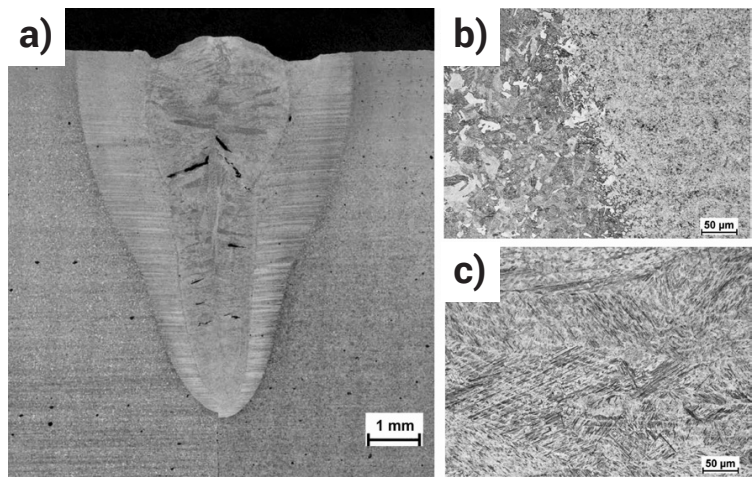

Rys. 7. Wyniki badań metalograficznych złącza doczołowego ze spoiną obwodową ze stali w gatunku 42CrMo4 spawanego wiązką elektronów z jednoczesnym podgrzewaniem i wygrzewaniem po spawaniu: a) widok złącza, b) obszar SWC, struktura: martenzyt, $624 \mathrm{HV}, \mathrm{c}$ ) obszar spoiny, struktura: martenzyt, $623 \mathrm{HV}$

Fig. 7. The results metallographic examinations of electron beam weIded butt joint of steel $42 \mathrm{CrMo} 4$ welded with same time preheating and heat treat after welding: a) joint view, b) the area $\mathrm{HAZ}$, structure: martensite, $624 \mathrm{HV}, \mathrm{c}$ ) the area of weld, structure: martensite, $623 \mathrm{HV}$
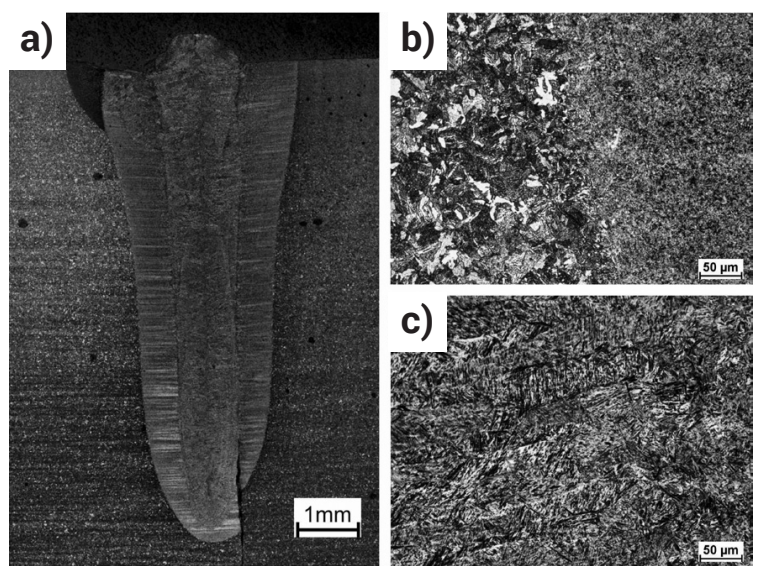

Rys. 8. Wyniki badań metalograficznych złącza doczołowego ze spoiną obwodową ze stali w gatunku 42CrMo4 spawanego wiązką elektronów z oscylacjami eliptycznymi, a) widok złącza, b) obszar SWC, struktura: martenzyt, 645 HV c) obszar spoiny, struktura: martenzyt, $637 \mathrm{HV}$

Fig. 8. The results metallographic examinations of electron beam welded butt joint of steel $42 \mathrm{CrMo} 4$ with elliptical oscillations: a) joint view, b) the area $\mathrm{HAZ}$, structure: martensite, $645 \mathrm{HV}$, c) the area of weld, structure: martensite, $637 \mathrm{HV}$ 
iż za pomocą wiązki elektronów wprowadzonej w oscylacje określonego rodzaju, o odpowiednio dobranej amplitudzie i częstotliwości oscylacji można w pewnym stopniu kształtować warunki krystalizacji spoiny. Z dwóch wyselekcjonowanych wstępnie rodzajów oscylacji do spawania elementów próbnych ze stali 42CrMo4 bardziej korzystne okazały się oscylacje eliptyczne. W złączach nie zaobserwowano bowiem charakterystycznych pęknięć wzdłużnych, choć badania metalograficzne mikroskopowe wykazały pojedyncze mikropęknięcia w obszarze spoiny. Średnia wartość twardości w spoinie wykonanej wiązką wprowadzoną w oscylacje eliptyczne była nieco niższa (637 HV) niż w przypadku spoiny wykonanej za pomocą wiązki wprowadzonej w oscylacje ósemkowe (670 HV).
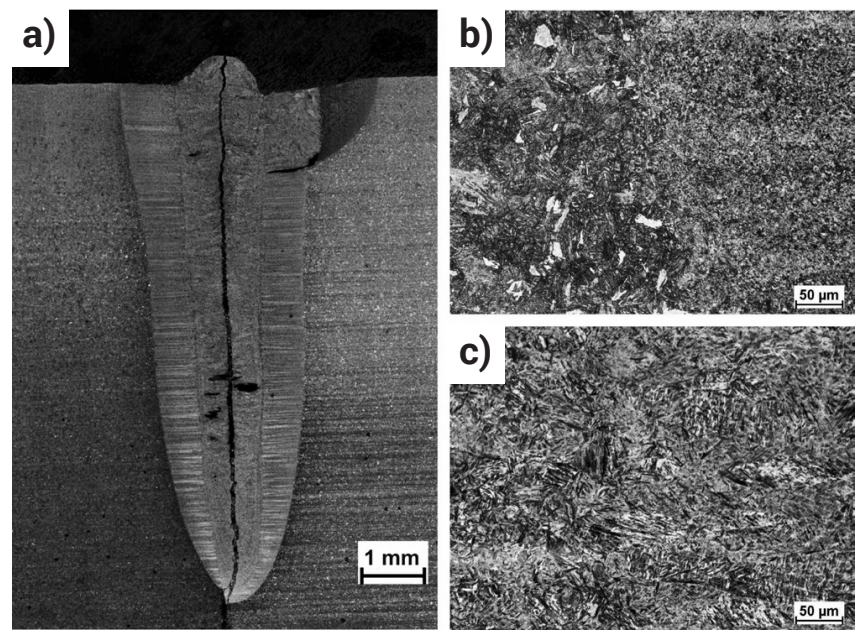

Rys. 9. Wyniki badań metalograficznych złącza doczołowego ze spoiną obwodową ze stali w gatunku 42CrMo4 spawanego wiązką elektronów z oscylacjami ósemkowymi, a) widok złącza, b) obszar SWC, struktura: martenzyt, 661 HV c) obszar spoiny, struktura: martenzyt, $670 \mathrm{HV}$

Fig. 9. The results metallographic examinations of electron beam welded butt joint of steel $42 \mathrm{CrMo} 4$ with octal oscillations: a) joint view, b) the area HAZ, structure: martensite, $661 \mathrm{HV}, \mathrm{c}$ ) the area of weld, structure: martensite, $670 \mathrm{HV}$

\section{Wnioski}

Na podstawie przeprowadzonych badań metalograficznych oraz pomiarów twardości obszarów poddanych odziaływaniu wiązki elektronów oraz złączy spawanych ze stali w gatunku 42CrMo4, można sformułować następujące wnioski:

- stosując oscylacje wiązki elektronów oraz techniki wieloprocesorowe, możliwe jest wpływanie na kształt spoiny oraz warunki krystalizacji,

- zastosowanie podgrzewania wstępnego do temperatury $400{ }^{\circ} \mathrm{C}$ umożliwiło wyeliminowanie pęknięć w obszarze spoiny i SWC oraz obniżenie twardości w SWC (320HV 1) i spoinie (330HV1),

- zastosowanie wieloprocesowego spawania pozwala na wyeliminowanie pęknięć wzdłuż osi złącza, jednak obserwuje się pęknięcia poprzeczne,

- zastosowanie oscylacji wiązki elektronów nie pozwoliło wyeliminować pęknięć w obszarze spoiny.

Dalsze badania będą miały na celu określenie wpływu warunków technologicznych prowadzenia procesu spawania wiązką elektronów na jakość złączy (z punktu widzenia wymagań norm) oraz szczegółowej analizy procesu krystalizacji spoiny.

Badania były prowadzone w ramach działalności statutowej w Instytucie Spawalnictwa i finansowane przez Ministerstwo Nauki i Szkolnictwa Wyższego.

\section{Literatura}

[1] M. St. Węglowski, S. Błacha, J. Dworak: Spawanie wiązką elektronów - charakterystyka metody. Biuletyn Instytutu Spawalnictwa, 58(2014), nr 3, 25-32.

[2] W. Behr. DVS Technical Codes on Electron Beam Welding. English edition, volume 8. DVS Media GmbH, Dusseldorf, 2013.

[3] M. St. Węglowski, J. Dworak, S. Błacha: Spawanie wiązką elektronów - urządzenia i wyposażenie". Biuletyn Instytutu Spawalnictwa, 58 (2014), nr 4, 22-30.

[4] Y. Arata, F. Matsuda, K. Nakata: Quench Hardening and Cracking in Electron Beam Weld Metal of Carbon and Low Alloy Hardenable Steels. Osaka University Konwledge Archive. http://ir.library.osaka-u.ac.jp/dspace/

[5] M.J. Bibby i inni.: Cracking in Restrained EB Welds in Carbon and Low Alloy Steels. Welding Journal, 8/1975.

[6] A.H. Meleka: Electron-beam Welding. Principles and Practice. McGraw-Hill Publishing Company Limited, 1971

[7] AWS C7.1M/C7.1:2013. An American National Standards. Recommended Practices for Electron Beam Welding and Allied Pracesses.

[8] H. Schultz H: Electron beam welding. Abington Publishing, Cambridge, Wielka Brytania, 1993.
[9] PN-EN 10083-3:2008. Stale do ulepszania cieplnego - Część 3: Warunki techniczne dostawy stali stopowych.

[10] Charakterystyki stali. Stale konstrukcyjne stopowe. Instytut Metalurgii Żelaza. Wydawnictwo Śląsk, 1975.

[11] D. Seferian: Metallurgie de la soudure. Paryż., Dunod, 1965

[12] E. Tasak: Metalurgia spawania. Kraków, 2008.

[13] Y. Ito, K. Bessyo: Weldability formula of high strength steels. Doc. IIW-II-512-69.

[14] PN-EN ISO 17639:2013-12. Badania niszczące spawanych złączy metali - Badania makroskopowe i mikroskopowe złączy spawanych.

[15] PN-EN ISO 9015-2:2011. Badania niszczące złączy spawanych metali - Badanie twardości - Część 2: Badanie mikrotwardości złączy spawanych łukowo.

[16] PN-EN ISO 15614-11:2005. Specyfikacja i kwalifikowanie technologii spawania metali. Badanie technologii spawania - Część 11: Spawanie wiązką elektronów i wiązką promieniowania laserowego.

[17] S. Błacha, M.St. Węglowski, S. Dymek, M. Kopuściański: Microstructural characterization and mechanical properties of electron beam welded joint of high strength steel grade S690QL, Archives of Metallurgy and Materials, vol. 61, No 2, 2016. 